\title{
Assessment of Hexavalent Chromium Pollution in Buriganga and Dhaleshwari River Waterbodies Adjacent to Tannery Estates in Bangladesh
}

\author{
Hafizur Rahman ${ }^{1 *}$, Nabila Hoque ${ }^{2}$, Palash K. Sarker³ ${ }^{3}$ and Ashrafus Safa ${ }^{4}$ \\ 1,2Department of Environmental Science, SESM, Independent University, Bangladesh (IUB), Dhaka, Bangladesh \\ ${ }^{3}$ Department of Science and Humanities, Military Institute of Science and Technology (MIST), Dhaka, Bangladesh \\ ${ }^{4}$ School of Life Sciences, Independent University, Bangladesh (IUB), Bangladesh \\ emails: ${ }^{*}$ hrahman@iub.edu.bd; ${ }^{2 n a b i l a h o q 111 @ g m a i l . c o m ; ~}{ }^{3}$ sarker@sh.mist.ac.bd; and ${ }^{4}$ asafa@iub.edu.bd
}

\section{ARTICLE INFO}

Article History:

Received: 22 2 fe Fruary 2020

Revised: $18^{\text {th }}$ March 2020

Accepted: $31^{\text {st }}$ March 2020

Published online: $21^{\text {st }}$ July 2020

\section{Keywords:}

Chromium

Tannery

Effluent

Buriganga

Dhaleshwari

\begin{abstract}
A B S T RAC T
Recently, in Bangladesh, all tannery industries have been relocated to a new location exclusively established for leather processing industries with modern manufacturing facilities and effluent treatment plants with standard probations. Effluents generated from the tannery industries are now being disposed of into the surrounding river water bodies. In this study, our goal was to investigate the presence of chemical contaminants like hexavalent chromium $\left(\mathbf{C r}^{6+}\right)$ in the water bodies surrounding tannery industries and to understand the possible role played by the tannery effluents in contaminating the river water bodies with $\boldsymbol{C r}^{6+}$. Result analysis revealed the presence of an amount of $\boldsymbol{C r}^{6+}$ (ranging from $\mathbf{0 . 0 1} \mathbf{~ m g} / \mathbf{L}$ to $3.54 \mathrm{mg} / \mathrm{L}$ ) in the surrounding water bodies, which was far above the maximum permissible limit of $\boldsymbol{C r}^{\mathbf{6}+}(\mathbf{0 . 0 5} \mathbf{m g} / \boldsymbol{L}$ for surface water), set by the Environmental Protection Agency. It is, therefore, plausible to assume that effluents from the tanneries play an important role in hexavalent chromium contamination of water bodies surrounding tannery industries.
\end{abstract}

\section{INTRODUCTION}

Leather industry is one of the key export sectors in Bangladesh. Currently, $>270$ registered tanneries are operating in Bangladesh (Rouf et al., 2013; Blacksmith Institute and Green Cross Switzerland, 2013; Hashem et al., 2014). Majority tanneries are situated at Hazaribagh area, located one and a half kilometer northeast to the river Buriganga in Dhaka, as shown in Figure 1 (Shams et al., 2009). A portion of the effluents from tanneries in Hazaribagh are transported to the lagoon while the other portion discharged into nearby low-lying areas through drain, which eventually falls into the Buriganga and introducing significant hazards in the surrounding environment (Hashem et al., 2015). It has already been reported that these tanneries discharge 1.6 tons of chromium per day, of which 0.35 tons are deposited into the lagoons and the remaining amount end up in the Buriganga (Karim et al., 2013). Generally, tannery waste contains both hexavalent and trivalent forms of chromium which are most stable and exist in the aqueous system. The hexavalent chromium is more toxic than its trivalent form and it is of particular concern for being carcinogenic and mutagenic to living organisms (Holmes et al., 2008; Saha et al., 2011; Zewdu \& Amare, 2018). In addition, highly toxic heavy metals such as copper, zinc, arsenic, cadmium, lead and organic compounds such as phenols, hydrocarbons and other toxic chemicals are found in Hazaribagh tannery area. (Shams et al., 2009; Karim et al., 2012; Tinni et al., 2014; Sarkar et al., 2015; Asaduzzaman et al., 2016; Juel et al., 2016). Exposure to these chemicals causes adverse health effects when they are not metabolized by the body and accumulated in the soft tissues. (Singh et al., 2004; Wilson and Pyatt, 2007). A number of residents in Hazaribagh were affected by pollution resulted from toxic chemicals, particularly chromium (Blacksmith Institute \& Green Cross Switzerland, 2013; Hossain \& Islam, 2016).

Considering the hazardous impact of tannery wastes on human and environment in Hazaribagh, Bangladesh government has planned a new strategy to resettle the tannery factories from their contemporary location to a new spot in Savar, which is known as 'Hazaribagh Tannery Relocation Project (HTRP)' (Jolly et al., 2012, Mahmood et al., 2017). The main focus of this relocation is to modernize the tanneries, and to treat the effluents through a modern common effluent treatment plant (CETP) before disposing of in the river water, which would finally evolve an appropriate waste management system for tannery industry. It is mentionable that Savar is an Upazila of Dhaka District, 
which is bounded to the west and south by the river Dhaleshwari, a linked river of Buriganga and the CETP is 20 kilometers far from Hazaribagh tannery area (RPMC, 2008; Islam et al., 2015). Therefore, contaminants might be transported with the water flow between these two rivers.

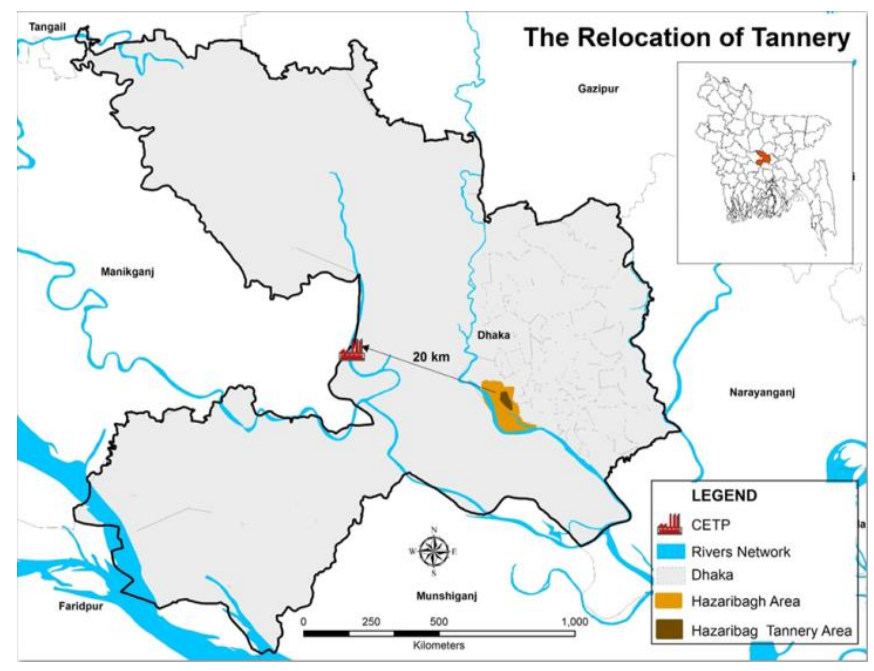

Figure 1: Map of tanneries in Hazaribagh and newly established estate in Savar

In the present study, we aim to determine the concentration of $\mathrm{Cr}^{6+}$ in the Buriganga and Dhaleshwari rivers from Hazaribagh and Savar tannery estates, respectively. The obtained data from this study will be helpful to understand the contamination level of the water bodies, that will facilitate to create people's awareness of chromium contamination from tannery waste disposal. Moreover, this study will be beneficial for the newly relocated tannery estate to make it more sustainable.

\section{METHODOLOGY}

\section{A. Sampling Site}

All the samples were collected from different categorized locations that are representative of the river flow, water source, drainage points, and treatment plant as shown in Figure 2 (a) and (b). There are two different study areas as shown in Figure 3 (a) and (b) for this project. All the samplings have been taken from the mentioned two areas, i.e., the Buriganga riverine area in Hazaribagh tannery estate and the Dhaleshwari riverine area in Savar tannery estate. The water samples were collected from 20 feet depth in each point which was marked by a global positioning system (Garmin eTrex 10) for future reference. It is mentionable that all the samples were taken at the rainy season between June and July while the water dilution of the rivers was much higher than the dry season.

\section{B. Reagents and Solutions}

All chemicals were of analytical-reagent grade and purchased from Sigma-Aldrich. Deionized water was used in the preparation of various solutions. A stock solution of potassium dichromate $\left(\mathrm{K}_{2} \mathrm{Cr}_{2} \mathrm{O}_{7}\right)$ of $1000 \mathrm{mg} / \mathrm{L}$ was prepared by weighing out an appropriate amount and dissolving it in deionized water. Working standards were prepared by consecutive dilution. Diphenylcarbazide solution was prepared by dissolving $1 \mathrm{~g}$ of 1,5-diphenylcarbazide (DPC), $\mathrm{CO}\left(\mathrm{NHNHC}_{6} \mathrm{H}_{5}\right)_{2}$, in $100 \mathrm{~mL}$ acetone and acidified with a drop of acetic acid.

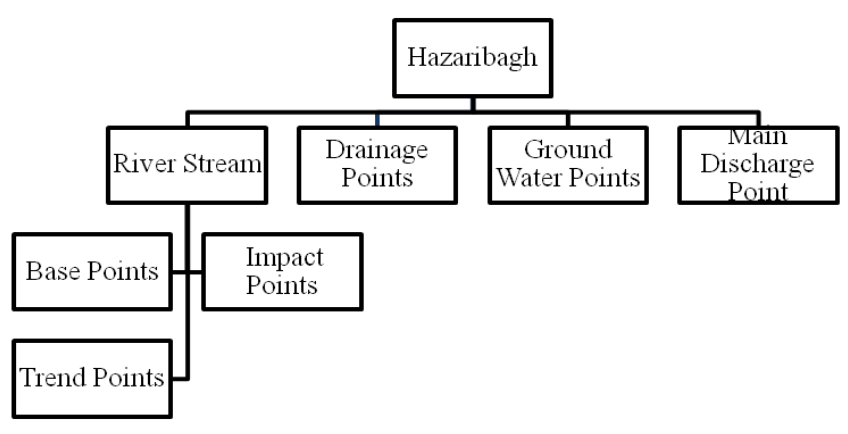

(a)

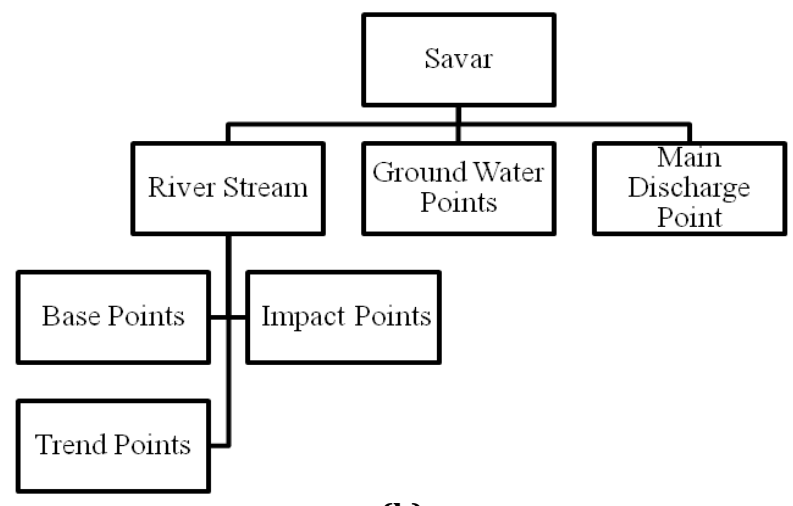

(b)

Figure 2: Categorized water samples collection points: (a) at Hazaribagh, and (b) at Savar

\section{UV Absorbance Measurement}

In this process, $20 \mathrm{~mL}$ of the sample was acidified with $1 \mathrm{~mL}$ of sulfuric acid and $1 \mathrm{~mL}$ of nitric acid. Then the sample was boiled properly for 10 minutes followed by cooling. The sample was then filtered with filter paper. Then the filtrate was taken into a volumetric flask and it was diluted with deionized water to adjust the volume into $20 \mathrm{~mL}$. After that, 2 drops of methyl orange were added in that adjusted $20 \mathrm{~mL}$ sample solution and the sample solution became orange in colour. Then the sample solution was titrated consecutively, firstly with a $28 \%$ ammonia solution until the colour turned yellow and secondly with 1: 1 sulfuric acid solution until the colour turned back into orange. After that the sample was boiled and cooled down, 2 drops of potassium dichromate was added to it followed by boiling. The colour of the sample turned into purple at this time. Then $1 \mathrm{~mL}$ of sodium azide was added followed by boiling again. All the colour had to disappear properly after the boil. If the colour did not disappear, another $1 \mathrm{~mL}$ of sodium azide was added to make the sample entirely colourless. The sample was properly cooled down to room temperature and $0.25 \mathrm{~mL}$ of orthophosphoric acid was added into the sample solution. The $p H$ level of the solution was found between $1.7-1.3$. Then, $20 \mathrm{~mL}$ of this solution was taken into another volumetric flask followed by the addition of $2 \mathrm{~mL}$ of sulfuric acid $(0.2 \mathrm{~N})$ and $2 \mathrm{~mL}$ of DPC solution. The volume of the solution was adjusted again to $50 \mathrm{~mL}$ with deionized water. In this method, $\operatorname{Cr}(V I)$ was reacted with DPC in acidic conditions and formed a purple-coloured species. As a result of a redox reaction, $\operatorname{Cr}(V I)$ was reduced to $C r(I I I)$, and DPC was oxidized to 1,5-diphenylcarbazone as shown in Figure 4. Finally, the wavelength of UV-Vis spectrophotometer (HACH, DR2800) was adjusted at $540 \mathrm{~nm}$ to measure the absorbance of the samples (Onchoke \& Sasu, 2016). 

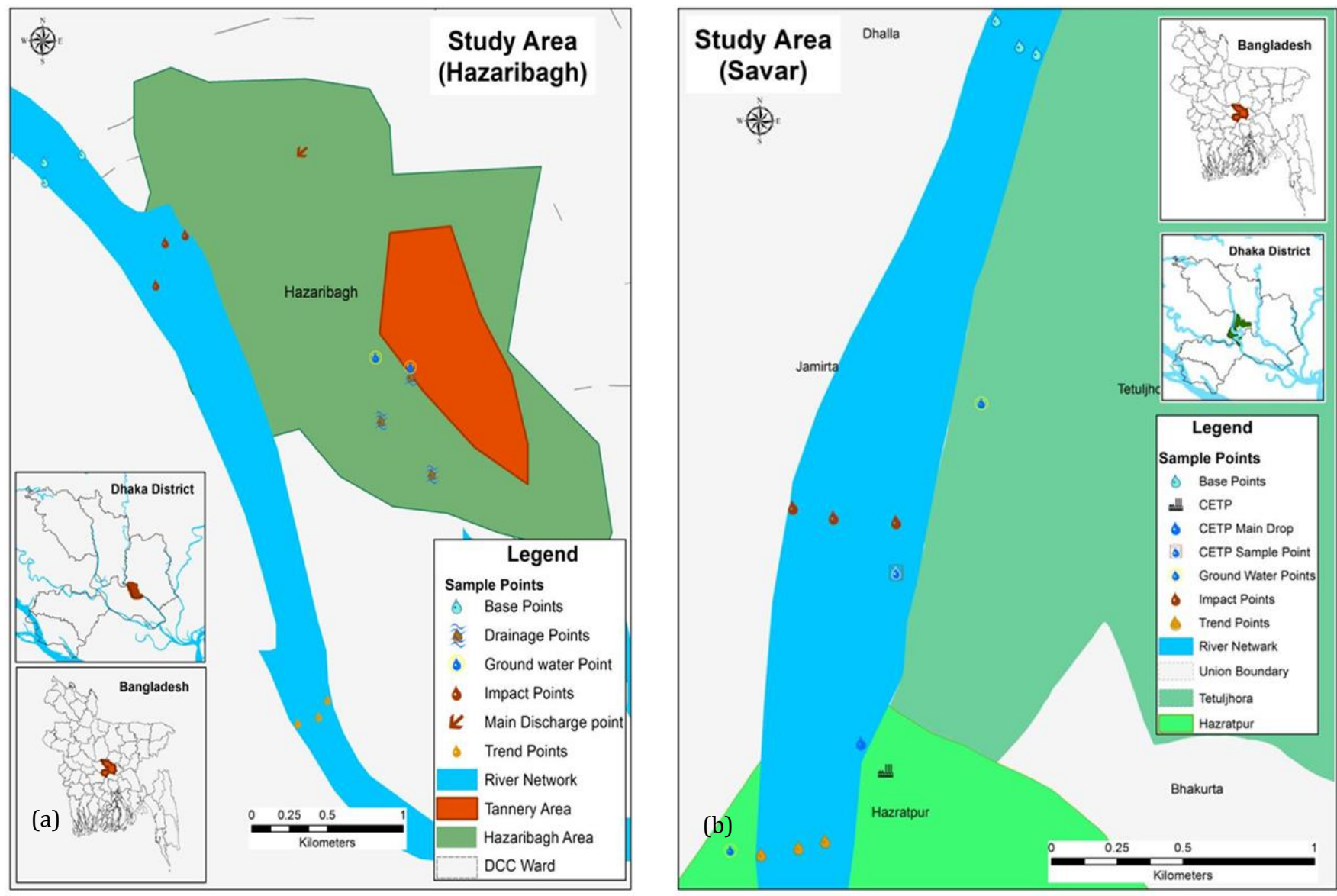

Figure 3: Map showing, (a) the study area at Hazaribagh, and (b) the study area at Savar

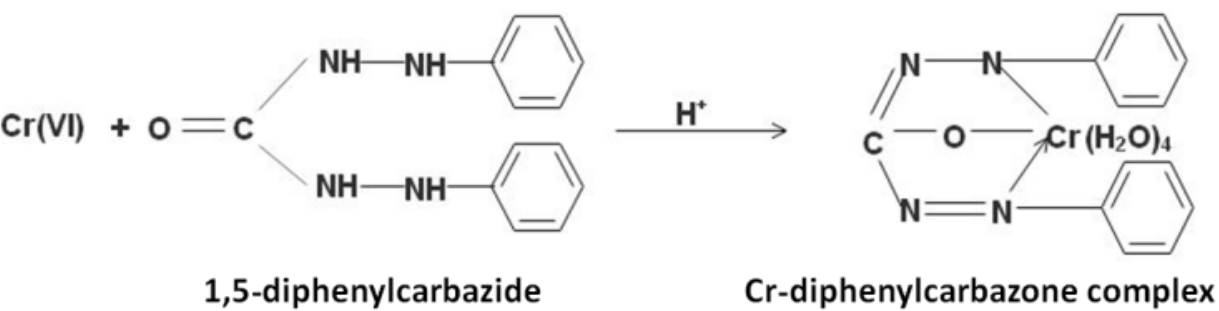

Figure 4: The chemical reaction between chromium (VI) and diphenylcarbazide to form chromium-diphenylcarbazone

\section{RESULTS AND DISCUSSION}

$\mathrm{Cr}^{6+}$ was detected in both study areas. However, the concentration was alarming in the drainage streams of Hazaribagh, because of the huge amount of basic chromium sulfate which is discharged from the adjacent leather processing and tanning industries. The effluents generated from those tanneries are dumped either directly into the nearby Buriganga river without any treatment or through drainage system. Sometimes, the industries use small lagoons to keep their effluents temporarily. Solid wastes are managed through open dumping methods near the industries or river and leachate comes in the environment very often. However, all the effluents discharged from the tanneries somehow end up in the Buriganga river through point and non-point sources.

The detected concentration of $\mathrm{Cr}^{6+}$ in the samples collected from Hazaribagh area were ranging from $0.01 \mathrm{mg} / \mathrm{L}$ to $3.54 \mathrm{mg} / \mathrm{L}$ as shown in Table 1 and Table 2.
Table 1

Chromium level at trend, impact and base points in Hazaribagh and Savar

\begin{tabular}{lcc}
\hline \hline \multirow{2}{*}{$\begin{array}{l}\text { pampling } \\
\text { points }\end{array}$} & $\begin{array}{c}\text { Hazaribagh } \\
\text { area }\end{array}$ & $\begin{array}{c}\text { Savar } \\
\text { area }\end{array}$ \\
\cline { 2 - 3 } Chromium $(\mathbf{m g} / \boldsymbol{L})$ \\
\hline Trend FS & 0.055 & 0.044 \\
Trend MS & 0.174 & 0.030 \\
Trend OS & 0.192 & 0.034 \\
Impact FS & 0.032 & 0.022 \\
Impact MS & 0.100 & 0.029 \\
Impact OS & 0.017 & 0.050 \\
Base FS & 0.052 & 0.038 \\
Base MS & 0.051 & 0.035 \\
Base OS & 0.010 & 0.029 \\
\hline \hline
\end{tabular}


Table 2

Chromium level at main discharge, drainage stream, groundwater, and CETP main drop points in Hazaribagh and Savar

\begin{tabular}{lcc}
\hline \hline $\begin{array}{l}\text { Sampling } \\
\text { points }\end{array}$ & $\begin{array}{c}\text { Hazaribagh } \\
\text { area }\end{array}$ & $\begin{array}{c}\text { Savar } \\
\text { area }\end{array}$ \\
\cline { 2 - 3 } $\begin{array}{l}\text { Chromium }(\mathbf{m g} / \mathbf{L}) \\
\text { (switch gate) }\end{array}$ & 3.460 & - \\
Drainage Stream 1 & 1.700 & - \\
Drainage Stream 2 & 3.540 & - \\
Drainage Stream 3 & 0.163 & - \\
Ground Water 1 & 0.028 & - \\
Ground Water 2 & 0.031 & - \\
CETP Main Drop Point & - & 0.032 \\
Ground FS & - & 0.029 \\
Ground OS & - & 0.033 \\
\hline \hline
\end{tabular}

Note: Trend means the point where the river Buriganga meets Dhaka city and around $2 \mathrm{~km}$ away from the tannery site. Impact is the river site adjacent to tanneries. Base is the point again $2 \mathrm{~km}$ away from the factory sites but when the discharge is taken away from the factory sites. FS means factory side of the river, MS means middle side of the river; OS means other side of the river.

Among them, the highest and the lowest concentration of $\mathrm{Cr}^{6+}$ were found in the drainage stream and in the Buriganga river water (Figure 5), respectively. The highest amount of chromium in the Buriganga river water was determined to be $0.192 \mathrm{mg} / \mathrm{L}$. Although, the concentration of hexavalent chromium in Buriganga river is less than Hazaribagh area drainage system-2 $(3.54 \mathrm{mg} / \mathrm{L})$ but still it is higher than the standard set by EPA 2001.

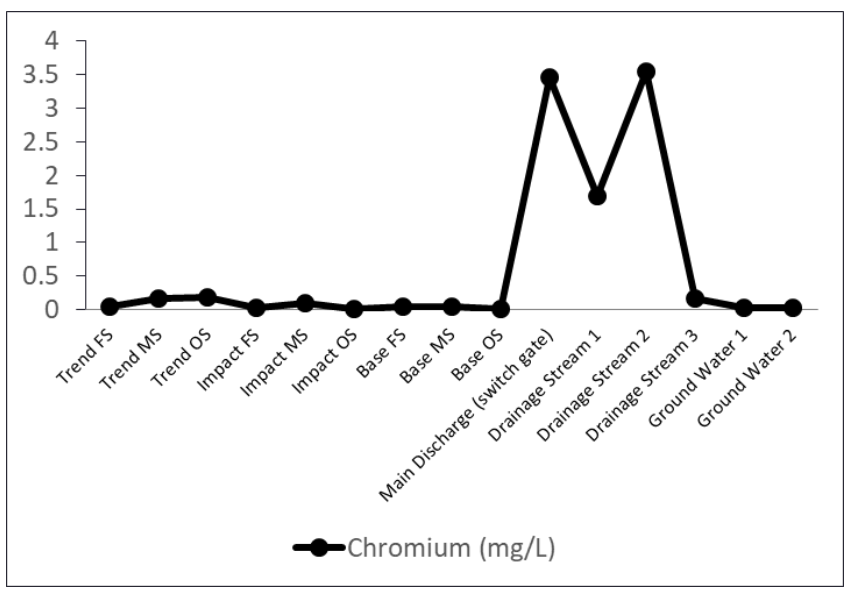

Figure 5: Concentration of $\mathrm{Cr}^{6+}$ in water bodies at different sampling locations in Hazaribagh area

On the other hand, the concentration of $\mathrm{Cr}^{6+}$ in Savar area was found in a range between $0.022 \mathrm{mg} / \mathrm{L}$ and $0.050 \mathrm{mg} / \mathrm{L}$ as shown in Table 1 and Table 2, which is identified within the standard limit set by EPA 2001. Eventually, the amount of hexavalent chromium (i.e., $0.032 \mathrm{mg} / \mathrm{L}$ ) at CETP main drop point is very reasonable. The presence of trace concentration of $\mathrm{Cr}^{6+}$ in Savar area (Figure 6) might cause due to the less efficiency of the newly established CETP or through the advection of the water flows between two rivers, the Buriganga and the Dhaleshwari. The river channels are also connected with each other, as shown in Figure 1. The distance between these two rivers is only 20 kilometers. So, the heavy metal chromium may travel through the water current by advection. Besides, chromium from the tannery waste can be leached into nearby soil and water, which could finally be the cause of the presence of $\mathrm{Cr}^{6+}$ with a meager amount in the Dhaleshwari river water. However, when all the tannery industries will be shifted to the new location and if the CETP fails to treat the effluents efficiently, the scenario would be the same as Hazaribagh.

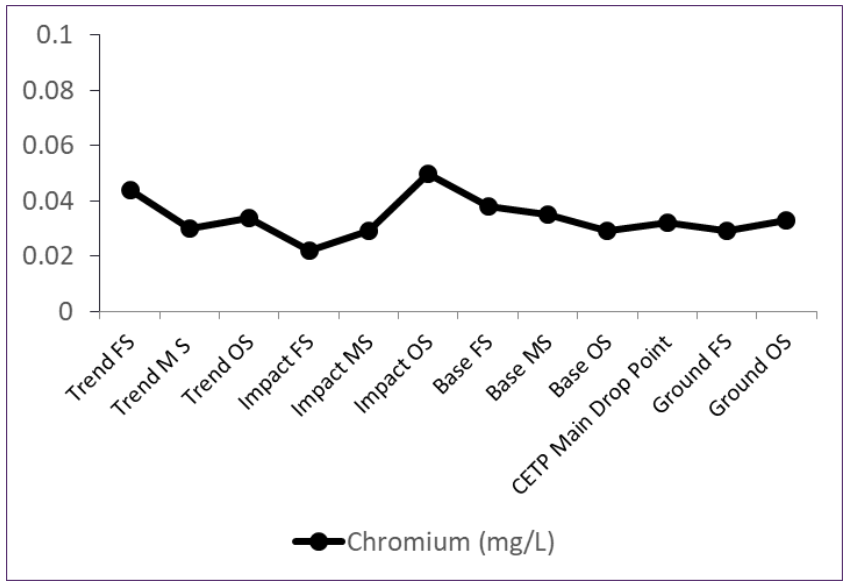

Figure 6: Concentration of $\mathrm{Cr}^{6+}$ in water bodies at different sampling locations in Savar area

\section{CONCLUSIONS}

The results of this study suggest that chromium $\left(\mathrm{Cr}^{6+}\right)$, a carcinogenic chemical released from tannery waste, is being introduced to Buriganga river water through different water bodies at Hazaribagh area. Consequently, it has been listed as one of the polluted places in Dhaka city. It is plausible that the removal of Hazaribagh tannery may reduce the Buriganga river pollution by a massive percentage. Relocation of all tanneries from Hazaribagh to Savar implemented by BSCIC (i.e., Bangladesh Small and Cottage Industries Corporation) with a properly designed and controlled new industrial estate will facilitate an ecologically friendly tannery business park in Bangladesh. So far, the results of our present study support so, especially considering the chromium contamination.

\section{ACKNOWLEDGEMENTS}

The authors are grateful to Ms. Shaheda Begum, Ms. Sonia Afsana, and Mr. Syed Ahmmed Kabir, Department of Environment, Government of the People's Republic of Bangladesh, Agargaon, Sher-e-Bangla Nagar, Dhaka-1207, Bangladesh, for their help in the sample collection and laboratory experiments. The authors would also like to thank Ms. Kazi Sunzida Lisa, Department of Environmental Management, Independent University Bangladesh (IUB), for her help to draw the GIS map.

\section{REFERENCES}

Asaduzzaman, M., Hasan, I., Rajia, S., Khan, N., \& Kabir, K. A. (2016). Impact of tannery effluents on the aquatic environment of the Buriganga River in Dhaka, Bangladesh. Toxicology and Industrial Health, 32(6), 1106-13. 
Blacksmith Institute and Green Cross Switzerland. (2013). The World's Worst 2013: The Top Ten Toxic Threats-Cleanup, Progress, and Ongoing Challenges. Retrieved February 22, 2020, from https://www.greencross.ch/wpcontent/uploads/uploads/media/pollution_report_2013_top_ten _wwpp.pdf

Hashem, M. A., Arefin, M. S., \& Ahmed, M. (2014). Estimation and Environmental Effect of Tannery Effluent from Wet Salted Goat Skin in Beam House Operations: Bangladesh Perspective. International Journal of Environment, 4(2), 3945.

Hashem, M. A., Islam, A., Mohsin, S., \& Nur-A-Tomal, M. S. (2015). Green environment suffers by discharging of highchromium containing wastewater from the tanneries at Hazaribagh, Bangladesh. Sustainable Water Resources Management, 1(4), 343-347.

Holmes, A. L., Wise, S. S., \& Wise, J. P. Sr. (2008). Carcinogenicity of hexavalent chromium. Indian Journal of Medical Research, 128(4), 353-72.

Hossain, M. A., \& Islam, L. N. (2016). Effect of Occupational Exposure on Allergic Diseases and Relationship with Serum $\operatorname{IgE}$ Levels in the Tannery Workers in Bangladesh. Bioresearch Communications, 2(1), 158-163.

Islam, M. S., Uddin, M. K., Tareq, S. M., Shammi, M., Kamal, A. K. I., Sugano, T., Kurasaki, M., Saito, T., Tanaka, S., \& Kuramitz, H. (2015). Alteration of Water Pollution Level with the Seasonal Changes in Mean Daily Discharge in Three Main Rivers around Dhaka City, Bangladesh. Environments, 2(3), 280-294.

Jolly, Y. N., Choudhury, T. R., Islam, A., \& Suravi, N. I. (2012). Background Chemical Study of Relocated Hazaribagh Tannery Complex Environment, Savar. Journal of Bangladesh Academy of Sciences, 36(1), 45-51.

Juel, M. A. I., Chowdhury, Z. U. M., Mizan, A., \& Alam, M. S. (2016). Toxicity and environmental impact assessment of heavy metals contaminated soil of Hazaribagh tannery area. In Proceedings of $3^{\text {rd }}$ International Conference on Advances in Civil Engineering, CUET, Chittagong, Bangladesh, 21-23 December 2016, (pp. 94-99).

Karim, M. R., Manshoven, S., Islam, M. R., Gascon, J. A., Ibarra, M., Diels, L., \& Rahman, M. M. (2013). Assessment of an Urban Contaminated Site from Tannery Industries in Dhaka City, Bangladesh. Journal of Hazardous, Toxic, and Radioactive Waste, 17(1), 52-61.

Mahmood, S., Nourin, F. T. J., Siddika, A., \& Khan, T. F. (2017). Encroachment of the Buriganga River in Bangladesh. Journal of Minerals and Materials Characterization and Engineering, 5, 266-273.

Onchoke, K. K., \& Sasu, S. A. (2016). Determination of Hexavalent Chromium (Cr(VI)) Concentrations via Ion Chromatography and UV-Vis Spectrophotometry in Samples Collected from Nacogdoches Wastewater Treatment Plant, East Texas (USA). Advances in Environmental Chemistry, 2016, 1-10.

River Pollution Mitigation Committee (RPMC). (2008). Mitigation of River Pollution of Buriganga and Linked Rivers-Turag, TongiKhal, Balu, Sitalakhya and Dhaleswari. A report of RPMC Dhaka, Bangladesh, 2008.

Rouf, M., Islam, M., Haq, M., Ahmed, N., \& Rabeya, T. (2013). Characterization of effluents of leather industries in Hazaribagh area of Dhaka city. Bangladesh Journal of Scientific and Industrial Research, 48(3), 155-166.

Saha, R., Nandi, R., \& Saha, B. (2011). Sources and toxicity of hexavalent chromium. Journal of Coordination Chemistry, 64(10), 1782-1806.

Sarkar, M., Rahman, A., Islam, J., Ahmed, K., Uddin, M., \& Bhoumik, N. (2015). Study of hydrochemistry and pollution status of the Buriganga river, Bangladesh. Bangladesh Journal of Scientific and Industrial Research, 50(2), 123-134.

Shams, K. M., Tichy, G., Sager, M., Peer, T., Bashar, A., \& Jozic, M. (2009). Soil contamination from tannery wastes with emphasis on the fate and distribution of tri- and hexavalent chromium. Water, Air, and Soil Pollution, 199(1-4), 123-137.

Singh, K. P., Mohan, D., Sinha, S., \& Dalwani, R. (2004). Impact assessment of treated/untreated wastewater toxicants discharged by sewage treatment plants on health, agricultural, and environmental quality in the wastewater disposal area. Chemosphere, 55(2), 227-55.

Tinni, S., Islam, M., Fatima, K., \& Ali, M. (2014). Impact of Tanneries Waste Disposal on Environment in Some Selected Areas of Dhaka City Corporation. Journal of Environmental Science and Natural Resources, 7(1), 149-156.

Wilson, B., \& Pyatt, F. B. (2007). Heavy metal dispersion, persistance, and bioccumulation around an ancient copper mine situated in Anglesey, UK. Ecotoxicology and Environmental Safety, 66(2), 224-31.

Zewdu, F., \& Amare, M. (2018). Determination of the level of hexavalent, trivalent, and total chromium in the discharged effluent of Bahir Dar tannery using ICP-OES and UV-Visible spectrometry. Cogent Chemistry, 4(1), 1534566. 